\title{
PERGESERAN NILAI HAK WARIS TERHADAP ANAK LUAR KAWIN DIAKUI (Studi Kasus Putusan Nomor 239/Pdt.G/2015/PN.JKT.PST)
}

\section{Vidya Pradipta}

(Mahasiswa Program S1 Fakultas Hukum Universitas Tarumanagara)

(E-mail: vidyapradipta@yahoo.com)

\section{Imelda Martinelli}

(Corresponding Author)

(Dosen Hukum Perdata Fakultas Hukum Universitas Tarumanagara, Meraih Sarjana Hukum dari Fakultas Hukum Universitas Tarumanagara (1990), Magister Hukum dari Fakultas Hukum Universitas

Tarumanagara (2002))

(E-mail: imeldam@fh.untar.ac.id)

\begin{abstract}
Illegitimate children that has been acknowledged are recognized as heirs who do not belong to the heirs class and cannot stand on their own but rather, they attach themselves to other heirs class. According to article 863 of the civil code law, outsiders are admitted to inheritance along with first heirs class is entitled to inherit 1/3 of those who should have been granted if they were legitimate children. In this case study, outsiders are recognized to have equal share of the estate with their legitimate children, indicating a distinction between applicable legislation and the development of values living in the community. The problem in this paper is how the shift in the value of inheritance rights to illegitimate children that has been acknowledged. The research method used is normative law research method, which is analyzed deductively. The results of the writing illustrate that there is a shift in the value of inheritance rights to illegitimate children that has been acknowledged where an illegitimate child that has been acknowledged is now recognized 'equal' as a legitimate child supported by argumentum per analogiam which analogies adopted child and the illegitimate child that has been acknowledged in terms of inheritance, three general precepts by Radbruch that prioritizes justice by observing the principle of fair equality of opportunity as long as it provides benefits and no harm to others, the theory of the legal system which not only refers to the substance of the law, but also see the culture or legal culture.
\end{abstract}

Keywords: shifting values, inheritance rights, illegitimate children are acknowleged.

\section{PENDAhuluan}

\section{A. Latar Belakang}


Masyarakat terdiri dari manusia baik sebagai perorangan (individu) atau kelompok manusia yang telah berhimpun untuk berbagai keperluan dan tujuan. Kehidupan manusia dalam perjalanannya mengalami tiga peristiwa penting, yaitu ketika ia lahir, menikah, dan meninggal dunia. Perkawinan merupakan suatu peristiwa penting dalam kehidupan manusia. Subekti berpendapat bahwa perkawinan diartikan sebagai pertalian yang sah antara seorang lelaki dan seorang perempuan untuk waktu yang lama. ${ }^{1)}$ Melalui perkawinan, manusia dapat membangun dan membina sebuah keluarga yang bahagia serta melanjutkan keturunan. Perkawinan diatur dalam Burgerlijk Wetboek (BW) atau Kitab Undang-undang Hukum Perdata (KUHPerdata) yang memandang perkawinan sebagai hubungan keperdataan (Pasal 26), ini berarti KUHPerdata tidak mengakui perkawinan menurut hukum agama. Selaras dengan hal tersebut, dikatakan dalam Pasal 1 Undang-Undang Nomor 1 Tahun 1974 tentang Perkawinan (UUP) bahwa yang menjadi tujuan perkawinan sebagai suami istri adalah untuk membentuk keluarga (rumah tangga) yang bahagia dan kekal berdasarkan Ketuhanan Yang Maha Esa.

Perkawinan menimbulkan akibat hukum bagi pihak suami dan istri dalam perkawinan, antara lain mengenai hubungan hukum di antara suami dan istri, terbentuknya harta benda perkawinan, kedudukan dan status anak yang sah, serta hubungan pewarisan. ${ }^{2)}$ Akibat hukum perkawinan tersebut hanya dapat diperoleh apabila perkawinan dilakukan secara sah memenuhi ketentuan Pasal 2 Ayat (1) dan Ayat (2) UUP, yaitu perkawinan dilakukan menurut hukum masing-masing agama dan kepercayaannya, serta dicatat menurut peraturan perundang-undangan yang berlaku.

Berbicara mengenai pewarisan berkaitan dengan peristiwa hukum, yaitu kematian. Setelah peristiwa kematian tersebut, timbullah akibat hukum ialah

\footnotetext{
${ }^{1)}$ Subekti, Pokok-pokok Hukum Perdata. Cetakan ke-31 (Jakarta: Intermasa, 2003), 23.

${ }^{2)}$ ]Sonny Dewi Judiasih, Harta Benda Perkawinan Kajian terhadap Kesetaraan Hak dan Kedudukan Suami dan Isteri atas Kepemilikan Harta dalam Perkawinan, Cetakan ke-1 (Bandung: PT Refika Aditama, 2015), 3.
} 
masalah bagaimana pengurusan dan kelanjutan hak-hak dan kewajibankewajiban seseorang yang meninggal dunia tersebut. Penyelesaian hak dan kewajiban seseorang yang meninggal diatur oleh hukum waris. Menurut Pitlo, hukum waris adalah suatu rangkaian ketentuan-ketentuan, di mana, berhubung dengan meninggalnya seorang, akibat-akibatnya di dalam bidang kebendaan, diatur, yaitu: akibat dari beralihnya harta peninggalan dari seseorang yang meninggal, kepada ahli-waris, baik di dalam hubungannya antara mereka sendiri, maupun dengan pihak ketiga. ${ }^{3)}$

Hukum waris di Indonesia masih bersifat pluralistis mengingat beraneka ragamnya corak budaya, agama, sosial, dan adat istiadat serta sistem kekeluargaan yang hidup dan berkembang di dalam masyarakat Indonesia. Penulisan ini membahas hukum waris barat yang ditempatkan dalam Buku II KUHPerdata (tentang Benda). Hukum waris tidak hanya terdapat aspek hukum benda saja, tetapi terdapat juga aspek-aspek lainnya, meskipun tidak dapat disangkal bahwa sebenarnya Hukum Waris termasuk dalam hukum harta. ${ }^{4)}$

Harta peninggalan adalah kekayaan yang berupa seluruh aktiva dan pasiva yang ditinggalkan Pewaris yang dapat berpindah kepada para ahli waris. Dalam harta peninggalan tersebut, termasuk didalamnya harta benda perkawinan. Dalam KUHPerdata diatur bahwa harta benda kedua mempelai suami istri menjadi milik bersama sejak perkawinan dilangsungkan, kecuali kalau diadakan perjanjian kawin untuk menyimpang dari prinsip tersebut.

R Wirjono Prodjodikoro, memberikan batasan-batasan mengenai warisan, antara lain: ${ }^{5)}$

1. Seseorang yang meninggalkan warisan (Erflater) pada saat orang tersebut meninggal dunia.

3) Ali Afandi, Hukum Waris, Hukum Keluarga, dan Hukum Pembuktian, Cetakan ke-4 (Jakarta: PT Rineka Cipta, 2004), 7.

4) L.J. van Apeldoorn, Pengantar Ilmu Hukum, diterjemahkan oleh Oetarid Sadino (Jakarta: Pradnya Paramita, 1993), 222.

5) Oemarsalim, Dasar-Dasar Hukum Waris di Indonesia, Cetakan ke-6 (Jakarta: PT Rineka Cipta, 2006). 4. 
2. Seseorang atau beberapa ahli waris (Erfenaam), yang mempunyai hak menerima kekayaan yang ditinggalkannya itu.

3. Harta warisan (nalaten schap), yaitu wujud kekayaan yang ditinggalkan dan selalu beralih kepada ahli waris tersebut.

Ahli waris menurut hukum waris barat dibagi menjadi empat golongan dengan bagiannya yang masing-masing diatur dalam KUHPerdata, yaitu:

1. Ahli Waris Golongan Satu, yaitu: anak-anak dan keturunannya serta suami atau istri yang hidup terlama.

2. Ahli Waris Golongan Dua, yaitu: orang tua, saudara laki-laki, saudara perempuan, dan keturunan saudara laki dan perempuan tersebut.

3. Ahli Waris Golongan Tiga, yaitu: sekalian keluarga dalam garis lurus ke atas, baik dari garis ayah maupun ibu.

4. Ahli Waris Golongan Empat, yaitu: keluarga sedarah lainnya dalam garis menyimpang sampai derajat ke enam.

Selain ahli waris yang masuk dalam golongan di atas, anak luar kawin diakui termasuk pula sebagai ahli waris. Melihat dari pengertian anak sah dalam UUP, dapat diasumsikan bahwa anak luar kawin adalah anak yang tidak dilahirkan dalam atau sebagai akibat perkawinan yang sah dan hanya mempunyai hubungan keperdataan dengan ibunya saja. Hak waris anak luar kawin timbul jika pewaris mengakui dengan sah anak luar kawin tersebut. Anak luar kawin diakui mewaris bersama semua golongan ahli waris. Besar bagian yang diterima tergantung dengan golongan mana anak luar kawin diakui tersebut mewaris, atau tergantung dari derajat hubungan kekeluargaan dari para ahli waris yang sah. ${ }^{6)}$

Penulisan ini ditujukan untuk memahami lebih lanjut mengenai anak luar kawin diakui sebagai ahli waris, penulis menggunakan studi kasus Putusan Pengadilan Negeri Nomor 239/Pdt.G/2015/PN.JKT.PST. Dalam putusan

6) J.G. Klaseen dan J.E. Eggens, Hukum Waris Bagian 1, Saduran dari Huwelijks Goederen en Erfrecht, Literatur Wajib pada Jurusan Notariat Fakultas Hukum Universitas Indonesia. (Jakarta:1979), 59. 
tersebut dinyatakan bahwa Pewaris meninggal dunia pada tanggal 17 Maret 2014. Pewaris semasa hidupnya melangsungkan perkawinan sebanyak tiga kali, perkawinan pertamanya pada tanggal 9 April 1967 berdasarkan Surat Perkawinan Keuskupan Agung Jakarta tanggal 15 Mei 2013 melahirkan empat orang anak yang dicatatkan sebagai anak luar kawin diakui oleh Pewaris. Pernikahan keduanya pada tanggal 22 Juli 1980 berdasarkan Akta Perkawinan yang sah melahirkan dua orang anakPernikahan ketiganya pada tanggal 30 Desember 2011 di Kantor Urusan Agama dan tidak memiliki anak.

Dalam perkawinannya diatur harta persatuan bulat, sehingga harta yang ia miliki merupakan harta bersama dalam perkawinannya yang mana harus diperhatikan tahun didapatkannya harta-harta tersebut serta tanggal perkawinan pertama, kedua, serta ketiganya. Salah satu harta warisan merupakan harta yang diperoleh selama perkawinan pertama dan keduanya, sedangkan harta warisan lainnya merupakan harta yang diperoleh selama perkawinan kedua dan ketiganya. Berdasarkan hal tersebut, sebelum dilakukan pembagian harta warisan, dilakukanlah terlebih dahulu pembagian harta bersamanya, barulah kemudian dibagi harta warisannya kepada setiap ahli waris.

Studi kasus putusan ini menyatakan bahwa istri dari perkawinan kedua dan ketiga serta para keturunan dari istri pertama dan kedua sebagai ahli waris dan menetapkan bagian untuk para ahli waris adalah sama bagiannya. Berlainan dengan putusan tersebut, seharusnya anak yang dilahirkan dari perkawinan pertama Pewaris merupakan anak luar kawin diakui oleh Pewaris tepat merupakan sebagai ahli waris, namun bagian anak luar kawin diakui tersebut memiliki bagian sendiri. Dalam hal ini, anak luar kawin tersebut mewaris bersama golongan satu. Sebagaimana diatur dalam Pasal 863 KUHPerdata bahwa bila Pewaris meninggal dengan meninggalkan keturunan yang sah dan atau suami istri, maka anak luar kawin diakui mewaris 1/3 bagian, dari mereka yang sedia-nya harus mendapat, seandainya mereka adalah anak sah. Akan 
tetapi, dalam putusan ditetapkan bahwa bagian anak luar kawin diakui tersebut adalah sama bagiannya dengan anak sah.

Adanya perbedaan antara teori dan perkembangan pada prakteknya seperti tergambar dalam studi kasus penulisan ini, perbedaan yang terjadi dikarenakan adanya pergeseran nilai hak waris terhadap anak luar kawin diakui dari pembuat undang-undang dan nilainya dalam perkembangannya pada masa ini. Manusia itu adalah mahluk yang dengan perbuatannya berhasrat untuk mencapai atau merealisasikan nilai. Standar umum yang dapat dikatakan tentang arti nilai, bahwa nilai merupakan sesuatu yang menarik bagi kita, sesuatu yang disukai dan diinginkan, singkatnya sesuatu yang baik. ${ }^{7)}$ Nilai berkembang seiring waktu, dari zaman ke zaman yang senantiasa menuntut keseimbangan untuk terus hadir dalam diri, hidup, dan kehidupan. Perbuatan yang dahulunya bernilai sangat baik, kini bisa saja dianggap biasa saja, begitu pula sebaliknya. Dapat dilihat adanya pergeseran nilai yang hidup dalam masyarakat dengan diikuti penyeimbang baru untuk melengkapinya, yaitu teori tujuan hukum, argumentum per analogiam, teori sistem hukum, dan teori nilai.

Berdasarkan latar belakang tersebut di atas untuk mendalami dan menuangkan kasus tersebut maka diangkatlah proposal penulisan skripsi dengan judul: "Pergeseran Nilai Hak Waris terhadap Anak Luar Kawin Diakui (Studi Kasus Putusan Nomor 239/Pdt.G/2015/PN.JKT.PST)."

\section{B. Permasalahan}

Berdasarkan uraian latar belakang di atas, maka permasalahan yang hendak dirumuskan adalah bagaimana pergeseran nilai hak waris terhadap anak luar kawin diakui (studi kasus Putusan Nomor 239/Pdt.G/2015/PN.JKT.PST)?

\section{Metode Penelitian}

7) Muhamad Erwin, Filsafat Hukum: Refleksi Kritis terhadap Hukum dan Hukum Indonesia (dalam Dimensi Ide dan Aplikasi) (Jakarta: PT Raja Grafindo Persada, 2011), 84. 
Penting bagi setiap karya ilmiah untuk mencantumkan metode penelitian, karena bila naskah tidak dilengkapi dengan metode penelitian, naskah akan dengan mudah di tolak dan dipertanyakan isinya. ${ }^{8)}$ Metode penelitian hukum merupakan suatu proses untuk menemukan aturan hukum, prinsip hukum, maupun doktrin hukum guna menjawab isu hukum yang akan dihadapi.

\section{Jenis Penelitian}

Untuk menjawab permasalahan yang telah dirumuskan dalam penelitian ini maka metode yang digunakan penelitian ini adalah metode penelitian normatif. Metode penelitian hukum normatif yaitu suatu proses untuk menemukan suatu aturan hukum, asas-asas hukum, maupun doktrin-doktrin hukum untuk menjawab permasalahan hukum yang dihadapi. ${ }^{9)}$

\section{Pendekatan Penelitian}

Pendekatan yang digunakan adalah pendekatan undang-undang, pendekatan kasus, dan pendekatan konseptual. Pendekatan undang-undang (statue approach) adalah pendekatan yang dilakukan dengan menelaah semua undang-undang dan regulasi yang bersangkut paut dengan isu hukum yang sedang ditangani. ${ }^{10)}$ Pendekatan kasus (case approach) dilakukan dengan cara melakukan telaah terhadap kasus-kasus yang berkaitan dengan isu yang dihadapi yang telah menjadi putusan pengadilan yang telah mempunyai kekuatan hukum tetap. ${ }^{11)}$ Pendekatan Konseptual beranjak dari pandangan-pandangan dan doktrin-doktrin yang berkembang di dalam ilmu hukum. $^{12)}$

\section{Jenis dan Sumber Data}

${ }^{8)}$ Peter Mahmud Marzuki, Penelitian Hukum. Edisi Revisi (Jakarta: Kencana Prenada Media Group, 2009), 3.

9) Mukti Fajar ND dan Yulianto Achmad, Dualisme Penelitian Hukum Normatif dan Empiri, (Yogyakarta: Pustaka Belajar, 2015), 34.

10) Ibid., 133.

11) Ibid., 134.

12) Ibid., 135. 
Teknik pengumpulan data yang digunakan dalam penelitian ini adalah dengan studi kepustakaan yang dilakukan melalui pengumpulan dari data sekunder, di mana data diperoleh dari bahan-bahan pustaka seperti buku dan dokumen tertulis lainnya. Adapun bahan hukum yang digunakan adalah:

a. Bahan Hukum Primer merupakan bahan hukum yang besifat autoritatif, artinya mempunyai otoritas. ${ }^{13)}$ Bahan hukum primer yang digunakan dalam penulisan ini adalah:

1) Kitab Undang-Undang Hukum Perdata;

2) Undang-Undang Nomor 1 Tahun 1974 tentang Perkawinan;

3) Peraturan Pemerintah Republik Indonesia Nomor 9 Tahun 1975 tentang Pelaksanaan Undang-Undang Nomor 1 Tahun 1974 tentang Perkawinan;

4) Putusan Pengadilan Negeri Jakarta Pusat Nomor 239/Pdt.G/2015/PN.JKT.PST.

b. Bahan Hukum Sekunder berupa semua publikasi tentang hukum yang bukan merupakan dokumen-dokumen resmi. ${ }^{14)}$ Bahan hukum sekunder yang digunakan dalam penulisan ini adalah berbagai kepustakaan hukum yakni buku atau jurnal hukum yang berisi mengenai prinsip-prinsip dasar (asas hukum), pandangan para ahli hukum (doktrin).

c. Bahan Hukum Tersier yakni bahan-bahan hukum yang memberi petunjuk serta penjelasan terhadap bahan hukum primer dan bahan hukum sekunder, ${ }^{15)}$ yakni merupakan Kamus Hukum dan Kamus Besar Bahasa Indonesia.

d. Bahan Non-Hukum dapat berupa buku-buku mengenai ilmu politik, ekonomi, sosiologi, filsafat, kebudayaan, ataupun laporan-laporan penelitian non-hukum, dan jurnal-jurnal non-hukum sepanjang

\footnotetext{
${ }^{13)}$ Peter Mahmud Marzuki, Op. Cit., 181.

14)Ibid., 190.

${ }^{15)}$ Soerjono Soekanto dan Sri Mamudji, Op. Cit., 13.
} 
mempunyai relevansi dengan topik penelitian yang kemudian sebatas sebagai pelengkap. ${ }^{16)}$ Wawancara juga merupakan bahan non-hukum.

\section{Spesifikasi Penelitian}

Spesifikasi data yang digunakan adalah deskriptif analisis yang bertujuan untuk menemukan, menggambarkan secara menyeluruh, dan mengkaji norma-norma hukum positif. ${ }^{17)}$ Penelitian hukum merupakan suatu kegiatan ilmiah yang didasarkan pada metode, sistematika dan pemikiran secara mendalam atas fakta hukum tersebut kemudian mengusahakan suatu pemecahan atas permasalahan-permasalahan yang timbul di dalam gejala yang bersangkutan.

\section{Teknik Analisis Penelitian}

Teknik analisis data penelitian ini menggunakan cara deduktif, yaitu menjelaskan suatu hal yang bersifat umum kemudian menariknya menjadi kesimpulan yang lebih khusus. ${ }^{18)}$

\section{PEMBAHASAN}

\section{A. Putusan Nomor 239/Pdt.G/2015/PN.JKT.PST}

1. Kasus Posisi

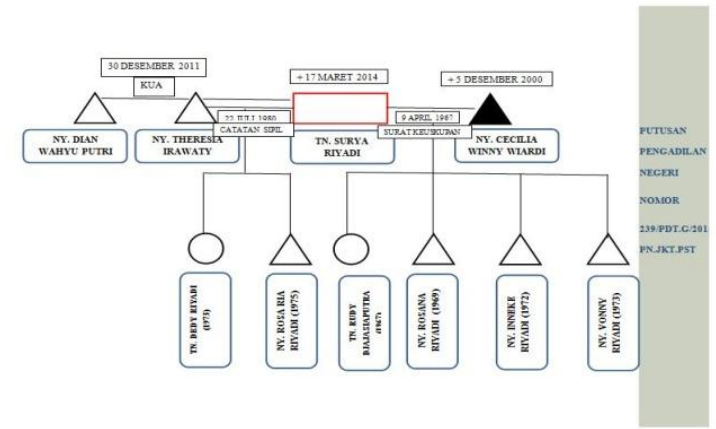

Gambar 1. Skema Kasus Posisi

\footnotetext{
16) Ibid., 183-184.

17) I Made Pasek Diantha, Metodologi Penelitian Hukum Normatif dalam Justifikasi Teori Hukum, Cetakan ke-1 (Jakarta: Prenada Media Group, 2016), 156.

${ }^{18)}$ Jujun S.Suriasumantri, Filsafat Ilmu, Cetakan ke-3 (Jakarta: Pustaka Sinar Harapan, 1987),
} 44. 
Dalam putusan tersebut dinyatakan bahwa Alm. Surya Riyadi (Pewaris) yang merupakan keturunan Tionghoa dan beragama Islam meninggal dunia pada tanggal 17 Maret 2014. Pewaris semasa hidupnya melangsungkan perkawinan sebanyak tiga kali, perkawinan pertamanya pada tanggal 9 April 1967 berdasarkan Surat Perkawinan Keuskupan Agung Jakarta tanggal 15 Mei 2013 dengan Alm. Cecilia Winny Wiardi yang meninggal pada tanggal 5 Desember 2000 melahirkan empat orang anak, yaitu Rudy Djajasia Putra (Penggugat II), Rosana Riyadi (Penggugat III), Inneke Riyadi (Penggugat IV), serta Vonny Riyadi (Penggugat V) yang dicatatkan sebagai anak luar kawin diakui oleh Pewaris. Pernikahan keduanya pada tanggal 22 Juli 1980 dengan Nyonya Theresia Irawaty (Tergugat I) berdasarkan Akta Perkawinan yang sah melahirkan dua orang anak, yaitu Dedy Riyadi (Tergugat II) dan Rosa Ria Riyadi (Tergugat III). Pernikahan ketiganya pada tanggal 30 Desember 2011 dengan Nonya Dian Wahyu Rahmi (Penggugat I) di Kantor Urusan Agama dan tidak memiliki anak.

Para Penggugat menggugat Para Tergugat melalui Pengadilan Negeri Jakarta Pusat. Adapun gugatan diajukan karena setelah meninggalnya Pewaris, belum dibuatkan Akta Pembagian Waris maupun Surat Keterangan Waris, dan adanya penguasaan sebagian harta peninggalan Pewaris oleh Para Tergugat. Para Pengugat memohon Pengadilan untuk menyatakan dan menetapkan harta peninggalan Pewaris, ahli waris yang sah dari Pewaris, bagian masing-masing ahli waris sama besar bagiannya atas seluruh harta waris peninggalan Pewaris atau sesuai dengan ketentuan hukum yang berlaku.

\section{Putusan Nomor 239/Pdt.G/2015/PN.JKT.PST}

a. Menyatakan Para Penggugat dan Para Tergugat sebagai ahli waris yang sah dari Pewaris;

b. Menyatakan harta benda sebagaimana telah disebutkan di atas; 
c. Menyatakan dan menetapkan bagian yang sama kepada masing-masing ahli waris atas seluruh harta waris (peninggalan) Pewaris.

\section{B. Pendapat Para Ahli Terhadap Putusan Nomor 239/Pdt.G/2015/PN.JKT.PST}

1. Bapak Eko Sugianto, S.H., M.H., selaku Hakim Ketua Majelis dalam Putusan Nomor 239/PDT.G/2015/PN.JKT.PST ${ }^{19)}$

Sah atau tidaknya perkawinan harus dilihat terlebih dahulu kapan perkawinan tersebut dilangsungkan, apabila dilangsungkan sebelum berlakunya UUP, maka perkawinan yang dilangsungkan secara agama saja sudah sah. Apabila dilangsungkan setelah berlakunya UUP, perkawinan adalah sah jika dilangsungkan menurut agamanya dan dicatatkan.

Adapun legal reasoning kami selaku majelis hakim dalam perkara ini memang tidak nampak dalam amar putusan, tinjauan kami terhadap perkara ini merujuk pada hukum nasional di Indonesia, kami memandang bahwa sudah tidak ada penggolongan penduduk, maka untuk hukum pewarisan, kami tidak lagi merujuk pada KUHPerdata. Dimana ke depannya yang akan berlaku hanyalah hukum kewarisan nasional, meskipun saat ini masih berupa rancangan dan dalam proses pembahasan. Dalam hukum kewarisan nasional ini, anak luar kawin diakui sama-sama mewaris terhadap harta gono-gini dipersamakan dengan anak angkat.

Pertimbangan hukum kami memang tidak tersebut dalam uraian putusan, namun bahwasannya anak luar kawin diakui kalau dibandingkan dengan anak angkat ada hal yang berbeda, anak luar kawin diakui jelas-jelas ayah biologisnya adalah ayah yang mengakui dan ibunya, sedangkan anak angkat ayah dan ibu biologisnya adalah orang lain. Kedudukan anak angkat dalam pewarisan memang tidak berhak untuk mewaris terhadap harta asal

19) Peneliti. Wawancara, dengan Eko Sugianto, S.H., M.H., selaku Hakim Ketua Majelis dalam Putusan Nomor 239/PDT.G/2015/PN.JKT.PST, (Jakarta, 30 April 2018). 
orang tua angkatnya, namun berhak mendapat harta gono-gini dari ayah dan ibu yang mengangkatnya, padahal ia jelas-jelas bukan anak biologisnya, ia memiliki kedudukan yang sama dengan anak sah terhadap harta gono-gini dari orangtua angkatnya.

Jika anak luar kawin diakui hanya mendapatkan $1 / 3$ bagian jika ia adalah anak sah dan dibandingkan dengan anak angkat, maka terdapat ketidakadilan bagi anak luar kawin diakui tersebut, dimana secara biologis ia benar anak biologis dari orangtuanya, namun karena perkawinan orang tuanya yang dilaksanakan setelah anak tersebut lahir, ataupun karena perkawinannya tidak dicatatkan yang mengakibatkan statusnya adalah anak luar kawin. Dibandingkan dengan anak angkat yang bahkan tidak memiliki hubungan biologis dengan orang tua angkatnya, namun berhak mewaris dan memiliki kedudukan yang sama dengan anak sah. Melihat dari hal tersebut, kami memandang adanya ketidakadilan dalam hal pewarisan ini, sehingga kami menyamakan dengan anak angkat, bagian anak luar kawin diakui ini sama bagiannya dengan anak sah bersama dengan pasangan yang hidup terlama dari pewaris.

2. Ibu Dr. Tjempaka, S.H., M.H., M.Kn., selaku Notaris dan Dosen di Fakultas Hukum Universitas Tarumanagara. ${ }^{20)}$

Kedudukan anak sah dan anak luar kawin diakui adalah sama, anak luar kawin diakui sama dengan anak sah serta bagiannya adalah sama, walaupun ada yang mengatakan bahwa bagian anak luar kawin diakui mewaris bersama golongan satu adalah 1/3 bagian dari bagiannya jika ia adalah anak sah. Anak luar kawin diakui sudah dianggap anak kandung, terlebih lagi dalam kasus ini bapaknya hanya satu dan pihak bapak sudah mengakui. Kuncinya terletak pada si bapaknya, jika sudah ada pengakuan dari bapaknya, maka anak luar kawin tersebut otomatis sama dengan anak sah.

\footnotetext{
${ }^{20)}$ Peneliti. Wawancara, dengan Dr. Tjempaka, S.H., M.H., M.Kn., selaku Notaris dan Dosen di Fakultas Hukum Universitas Tarumanagara, (Jakarta, 25 April 2018).
} 
Anak luar kawin diakui akan menjadi anak sah, namun statusnya tetap dikenal anak luar kawin diakui. Pengakuan tersebut juga memberlakukan hubungan keperdataan dengan keluarga si ayah yang mengakui.

3. Prof. Dr. Abdul Gani Abdullah, selaku Guru Besar dan Mantan Hakim Agung Bagian Perdata ${ }^{21)}$

Mengenai sah atau tidaknya perkawinan dalam hal menentukan pewarisan, hakim dapat menilai langsung apakah perkawinan tersebut sah atau tidak tanpa harus adanya pengesahan perkawinan secara resmi. Dalam hal pembagian waris, yang bapak ibunya tidak ada, perkawinan yang melahirkan anak ini harus dinyatakan sah terlebih dahulu oleh Pengadilan, yang akibat hukumnya menentukan siapakah ahli warisnya, apakah anakanak yang lahir dari perkawinan tersebut anak sah atau anak luar kawin.

Anak luar kawin ada dua macam, satu anak yang lahir dari suatu perkawinan yang sah menurut agama tapi belum dicatat, dan anak yang lahir dari hubungan laki-laki dan perempuan yang belum menikah. Kasus ini, anak yang lahir dari perkawinan pertama ini adalah anak yang sah menurut agama, hanya saja tidak dicatatkan menurut hukum. Anak luar kawin seperti ini termasuk ke dalam golongan anak sah hanya saja tidak terdaftar. Mengenai status dan hak, tepat jika anak dari perkawinan ini berhak atas bagian yang sama dengan anak sah, karena anak dari perkawinan pertama kasus ini termasuk dalam golongan anak sah hanya saja tidak dicatatakan.

Hukum kewarisan nasional yang masih berbentuk draft atau rancangan itu tidak dapat digunakan untuk menjadi dasar pertimbangan dalam suatu putusan. Rancangan itu tidak dapat memaksa orang untuk menerapkannya, tetapi kalau hakim memandang bahwa rancangan itu dapat menjadi hukum, itu akan menjadi hukum, harus dilihat terlebih dahulu apakah hakim benarbenar mengambil rancangan undang-undang tersebut sebagai dasar

21) Peneliti. Wawancara, dengan Prof. Dr. Abdul Gani Abdullah, selaku Guru Besar dan Mantan Hakim Agung bagian Perdata, (Jakarta, 22 Mei 2018). 
pertimbangannya. Jika iya, maka hakim tersebut mengambil pendapat perancang rancangan undang-undang tersebut menjadi hukum, dan itu diperbolehkan serta rancangan tersebut juga menjadi hukum.

\section{Analisis}

\section{Pergeseran Nilai Hak Waris terhadap Anak Luar Kawin Diakui (Studi} Kasus Putusan Nomor 239/Pdt.G/2015/PN.JKT.PST)

Perkawinan merupakan salah satu perbuatan hukum dalam masyarakat, yaitu peristiwa kemasyarakatan yang oleh hukum diberikan akibat hukum yang penting dalam kaitannya dengan sahnya perbuatan hukum tersebut. Melihat pada berbagai aturan tentang perkawinan, baik itu di dalam KUHPerdata maupun UUP, dapat disimpulkan bahwa suatu perkawinan adalah sah apabila perkawinan tersebut dilangsungkan menurut hukum masing-masing agama dan kepercayaannya serta dicatatkan di Kantor Catatan Sipil bagi yang non-muslim, di Kantor Urusan Agama bagi yang muslim. Kaitan dengan studi kasus ini, perkawinan pertama ini tidak memenuhi syarat sebagai suatu perkawinan yang sah karena tidak dilakukan pencatatan sebagaimana diatur dalam peraturan perundang-undangan.

Akibat hukum dari perkawinan, seperti hubungan hukum di antara suami istri, terbentuknya harta benda perkawinan, kedudukan dan status anak, serta hubungan pewarisan baru akan muncul apabila perkawinan tersebut adalah perkawinan yang sah. Mulanya, diatur dalam KUHPerdata bahwa sejak perkawinan dilangsungkan, berlakulah harta persatuan bulat antara suami dan istri, dimana tidak ada harta pribadi harta kekayaan dari suami dan istri, semua kekayaannya menjadi harta bersama sebagai akibat perkawinan yang sah. Akan tetapi, UUP memungkinkan adanya pemisahan harta antara suami dan istri dengan membuat perjanjian pemisahan harta sebelum atau saat melangsungkan perkawinan, maupun setelah melangsungkan perkawinan. Menelaah studi kasus penulisan ini, akibat 
perkawinan dari perkawinan pertama, kedua, dan ketiga seluruhnya terhadap harta perkawinan adalah harta persatuan bulat melihat tahun berlangsungnya perkawinan dan tidak adanya perjanjian pemisahan harta. Harta perkawinan ini berkaitan dengan pewarisan nantinya, dimana jika berlaku harta persatuan bulat, maka perlu diadakan pembagian harta gono-gini antara pewaris dengan pasangan yang hidup terlama terlebih dahulu sebelum pembagian harta warisan. Setelah pembagian harta gono-gini tersebut, barulah dapat dilakukan pembagian harta waris kepada sekalian ahli warisnya.

Selanjutnya, untuk melihat kedudukan dan status seorang anak, perlu dilihat dari kelahiran anak tersebut, apakah anak tersebut lahir dalam atau sebagai akibat dari suatu perkawinan yang sah atau tidak. Sebagaimana diatur dalam KUHPerdata maupun UUP, anak sah adalah anak yang lahir dalam atau sebagai akibat dari perkawinan yang sah. Berdasarkan pengaturan dalam KUHPerdata tentang "Kebapakan dan asal keturunan anak-anak", dapat disimpulkan terdapat 2 (dua) kedudukan anak, yaitu anak sah dan anak luar kawin. Anak sah yang merupakan anak yang lahir dalam atau sebagai akibat dari suatu perkawinan yang sah, sedangkan anak luar kawin yaitu anak yang dilahirkan dari hasil hubungan antara seorang lakilaki dengan seorang perempuan yang kedua-duanya sedang tidak terikat perkawinan dengan orang lain, dan yang diantara keduanya tidak ada larangan perkawinan, serta anak yang lahir dalam suatu ikatan perkawinan namun perkawinan tersebut belum memenuhi suatu perkawinan yang sah. Anak luar kawin dapat memiliki hubungan hukum dengan ibu dan ayahnya melalui sebuah pengakuan.

Status dan kedudukan anak ini penting guna menentukan kedudukan dan bagiannya sebagai ahli waris dalam suatu pewarisan. Pewarisan diatur dalam hukum waris yang mengatur bagaimana akibat hukum dan peralihan hak dan kewajiban seseorang terhadap harta kekayaannya kepada para ahli warisnya. 
Hukum waris di Indonesia masih bersifat pluralistis, studi kasus ini menggunakan hukum waris barat karena para pihak yang bersengketa keturunan tionghoa (tunduk pada KUHPerdata diatur dalam Stbld: 1924 No.557) dan beragama muslim dan non-muslim (Undang-Undang Nomor 7 Tahun 1989 tentang Peradilan Agama yang menyebutkan bahwa Peradilan Agama hanya berwenang untuk memeriksa dan mengadili sengketa waris yang terjadi bagi ahli waris/orang-orang yang bergama Islam, sedangkan para pihak yang bersengketa dalam kasus ini ada yang non-muslim). KUHPerdata mengatur bahwa anak luar kawin diakui berhak mewaris. Anak luar kawin diakui merupakan ahli waris yang tidak masuk ke dalam golongan ahli waris serta tidak dapat berdiri sendiri melainkan, ia mewaris bersama golongan ahli waris lainnya. Berdasarkan Pasal 863 KUHPerdata, anak luar kawin diakui mewaris bersama golongan satu berhak mewaris 1/3 bagian dari mereka yang sedianya harus mendapat seandainya mereka adalah anak sah. Jika menelaah studi kasus ini, tepatlah putusan pengadilan negeri yang menetapkan ahli waris dalam kasus ini. Kaitan dalam penulisan ini yang menekankan pada anak luar kawin diakui dan anak sah, adapun bagiannya berdasarkan peraturan yang berlaku, yakni KUHPerdata serta UUP adalah sebagai berikut:

\begin{tabular}{|c|c|c|}
\hline $\begin{array}{c}\text { Harta } \\
\text { Warisan }\end{array}$ & $\begin{array}{c}\text { Bagian Masing-masing } \\
\text { Anak Luar Kawin Diakui } \\
\text { (Rudy Djajasiaputra, } \\
\text { Rosana Riyadi, Inneke } \\
\text { Riyadi, Vonny Riyadi) }\end{array}$ & $\begin{array}{c}\text { Bagian Masing-masing Anak } \\
\text { Sah (Dedy Riyadi, Rosa Ria } \\
\text { Riyadi) }\end{array}$ \\
\hline I & $11 / 480$ & $11 / 96$ \\
\hline II & $1 / 48$ & $7 / 60$ \\
\hline III & $1 / 48$ & $7 / 60$ \\
\hline IV & $1 / 48$ & $7 / 60$ \\
\hline V & $1 / 48$ & $7 / 60$ \\
\hline
\end{tabular}

Tabel 1. Bagian Anak Luar Kawin Diakui dan Anak Sah dalam Studi Kasus berdasarkan KUHPerdata. 
Dapat dilihat dengan menggunakan Pasal 863 KUHPerdata sebagai dasar hukum dalam pewarisan studi kasus ini, anak luar kawin diakui berhak mewaris dalam hal ini bersama dengan ahli waris golongan satu (anak sah dan pasangan yang hidup terlama). Anak luar kawin diakui memiliki bagian sendiri dalam suatu pewarisan, berbeda dengan bagian anak sah, dikarenakan perbedaan status ahli waris antara keduanya. Status dan hak merupakan dua hal yang saling beriringan, sehingga hak waris seseorang bergantung pada status ahli waris orang tersebut. Adapun pembagian harta warisan yang ditetapkan terhadap studi kasus ini dalam Putusan Nomor 239/Pdt.G/2015/PN.JKT.PST, setiap ahli waris mendapat bagian yang sama.

Perbedaan yang terjadi antara aturan yang berlaku dengan yang terjadi dalam studi kasus ini didasari oleh dasar pertimbangan yang berbeda dimana dalam perkembangan ini akan adanya unifikasi hukum waris yang nantinya akan diatur dalam Hukum Kewarisan Nasional. Selain itu, berdasarkan data hasil wawancara dengan Ibu Tjempaka, dalam penerapannya di masyarakat anak luar kawin diakui, maka anak luar kawin tersebut berhak mewaris dan bagiannya dianggap sama dengan anak sah dalam suatu pewarisan. Ditambah pertimbangan Bapak Eko Sugianto yang menyatakan putusannya lebih mengutamakan keadilan sebagai tujuan hukum, Majelis Hakim memandang tidaklah adil bagi anak luar kawin diakui tersebut jika tidak mendapatkan bagian yang sama dengan anak sah.

Kedudukan Pengadilan atau Hakim penting dalam hal penerapan dan pengembangan hukum. Berlainan dengan pendapat Monstesquieu dalam bukunya “ $L$ 'Esprit de Lois" yang menyatakan bahwa Pengadilan atau Hakim hanya mulut atau corong dari badan legislatif. Dewasa ini, hakim tidak hanya menerapkan undang-undang, tetapi Hakim juga menemukan atau bahkan sering membentuk hukum baru (nampak pada Pasal 10 UndangUndang Nomor 48 Tahun 2009 tentang Kekuasaan Kehakiman). Ditambah asas Ius Curia Novit dimana hakim dianggap mengetahui dan memahami 
segala hukum. Melihat kententuan tersebut, nampak bahwa Pengadilan atau Hakim dalam sistem hukum Indonesia bukanlah Hakim yang pasif, namun aktif berperan di dalam menemukan hukum atau membentuk hukum baru. Sehubungan dengan hal tersebut, Pengadilan atau Hakim memiliki fungsi melengkapi ketentuan hukum tertulis melalui pembentukan hukum (rechtsvorming) dan penemuan hukum (rechtsvinding). Dalam menjalankan fungsinya, Pengadilan atau Hakim dapat menggunakan metode interpretasi, metode konstruksi (analogi), dan penghalusan hukum. Putusan Pengadilan atau Hakim hendaknya mampu memenuhi tiga tujuan hukum menurut Gustav Radbruch, yaitu: keadilan, kemanfataan, dan kepastian hukum.

Putusan Pengadilan atau Hakim yang ditetapkan haruslah adil, memberikan manfaat bagi masyarakat, serta berkepastian hukum. Sebagaimana pendapat seorang hakim terkenal di Indonesia, Bismar Siregar, apabila terjadi pertentangan antara kepastian hukum dan keadilan, keadilanlah yang harus terlebih dahulu ditegakkan. Guna menegakkan keadilan, kepastian hukum dapat dikorbankan, karena hukum hanyalah sarana dan keadilan adalah tujuan hukum. Selaras dengan majelis hakim dalam kasus ini yang putusannya lebih mengedepankan keadilan. Studi kasus ini memperlihatkan dimana peraturan yang berlaku, yakni KUHPerdata telah mengatur kedudukan dan berapa bagian anak luar kawin diakui dan anak sah, namun seiring berkembangnya masyarakat, nilai anak luar kawin diakui pun sudah berbeda. Dewasa kini, anak luar kawin diakui tidak lagi memiliki bagian sendiri. Anak luar kawin diakui yang sudah 'dianggap sama' dengan anak sah, maka nilai keadilan terhadap anak luar kawin diakui pun bergeser, karena ia 'dianggap sama' maka adil bagi mereka jika mereka memiliki hak waris atas bagian yang sama terhadap harta waris dengan anak sah.

Legal reasoning majelis hakim kasus ini selaras dengan teori keadilan John Rawls, sebagaimana dijelaskan keadilan sebagai liberty principle (asas 
kebebasan) dan difference principle (asas perbedaan). Menurut Rawls, perlu ada keseimbangan antara kepentingan pribadi dan kepentingan bersama. Asas kebebasan berarti setiap orang memiliki hak yang sama atas kebebasan dasar yang paling luas, asas ini dibutuhkan karena orang-orang selayaknya membutuhkan kesetaraan dalam penerapan hak dan kewajiban dasar. Asas perbedaan mengatur ketimpangan sosial dan ekonomi sehingga memenuhi kesetaraan peluang (fair equality of opportunity) dan keuntungan terbesar untuk anggota masyarakat yang paling kurang beruntung. Perbedaan sosial dan ekonomi harus diatur agar memberikan manfaat yang paling besar bagi mereka yang paling kurang beruntung untuk mencapai kesejahteraan. Keadilan diharapkan mampu mengatur kembali kesenjangan sosial ekonomi yang terjadi sehingga dapat memberi keuntungan timbal balik, baik mereka yang berasal dari pihak yang kuat dan beruntung maupun pihak yang lemah dan kurang beruntung. Kaitannya dalam kasus ini adalah anak luar kawin diakui yang diatur dalam KUHPerdata memiliki bagian sendiri dalam suatu pewarisan yang mana bagiannya lebih kecil jika dibandingkan dengan anak sah, kemudian adanya studi kasus ini yang berlainan dengan ketentuan dalam KUHPerdata, putusan dalam studi kasus ini menetapkan bagian hak waris anak luar diakui adalah sama bagiannya dengan anak sah. Di dukung skala prioritas dalam prinsip keadilan menurut Rawls yang mengutamakan prinsip kebebasan yang sama sebesar-besarnya, kemudian prinsip persamaan yang adil atas kesempatan dan terakhir prinsip perbedaan. Hakim dalam studi kasus ini memberikan hak yang sama atas seluruh keuntungan dalam hal ini anak luar kawin diakui mendapat bagian yang sama dengan anak sah sepanjang tidak merugikan orang lain. Selain itu, dalam rangka menjunjung tinggi keadilan sebagai tujuan hukum, majelis hakim memandang bahwa anak luar kawin diakui 'dianggap sama' dan berhak mendapat bagian yang sama dengan anak sah guna memberi hak dan kesempatan yang sama atas 
kebebasan dasar yang paling luas seluas kebebasan yang sama bagi tiap ahli waris.

Argumentum per analogiam digunakan dalam studi kasus ini dengan menganalogikan hubungan anak angkat dan anak sah dalam suatu pewarisan yang memiliki bagian yang sama terhadap harta warisan dengan hubungan anak luar kawin diakui dan anak sah dalam suatu pewarisan, maka anak luar kawin diakui 'dianggap sama' dengan anak sah dan berhak mendapatkan bagian yang sama seperti anak sah. Dianggap sama berarti anak luar kawin diakui dipandang sama dengan anak sah, dapat memiliki hak atas bagian yang sama dengan anak sah, walaupun status ahli warisnya tidak berubah dan tetap sebagai anak luar kawin diakui. Selaras dengan KBBI, sama berarti tidak berbeda, jika 'dipersamakan' maka tidak ada perbedaan sama sekali antara anak luar kawin diakui dengan anak sah, baik secara status ahli waris maupun hak warisnya. Berlainan dengan 'dianggap sama' yang hanya dipandang sama, tidak sama persis dan masih terdapat perbedaan, sehingga seperti anak luar kawin diakui yang dalam hal ini masih dapat berhak atas haknya mendapat bagian yang sama seperti anak sah, meskipun status ahli warisnya tidak berubah menjadi anak sah. Terlebih lagi, jika dibandingkan dengan anak angkat yang jelas bukan anak biologis dari Pewaris, walaupun setelah adanya pengangkatan anak yang dilakukan secara sah. Anak angkat tidak diatur dalam KUHPerdata, bagian anak angkat diatur dalam hukum adat, kaitannya dalam hal ini yaitu Warga Negara Indonesia keturunan Tionghoa, kedudukan anak angkat adalah sama dengan anak sah. Berdasarkan analogi tersebut, maka dapat ditarik kesimpulan bahwa anak luar kawin 'dianggap sama' dengan anak sah sehingga anak luar kawin diakui berhak atas bagian yang sama dengan anak sah walaupun status ahli warisnya berbeda.

Berkaitan pula dengan teori sistem hukum Lawrence M Friedman, dimana tidak hanya mengacu pada substansi hukum, yakni peraturan 
perundang-undangan yang berlaku. Sebaik apapun penataan struktur hukum untuk menjalankan aturan hukum yang ditetapkan dan sebaik apapun kualitas substansi hukum yang dibuat tanpa didukung budaya hukum oleh masyarakat yang terlibat dalam sistem hukum, maka penegakan hukum tidak akan berjalan secara efektif. Maka dari itu, perlu juga memperhatikan kultur hukum yang lebih mengarah pada sikap masyarakat, kepercayaan masyarakat, nilai-nilai yang dianut masyarakat dan ide-ide atau pengharapan mereka yang menentukan bagaimana sistem hukum memperoleh tempat yang sesuai dan dapat diterima oleh warga masyarakat dalam kerangka budaya masyarakat..

Nilai berkembang dalam kehidupan masyarakat, yang kemudian nilai tersebut diturunkan dalam bentuk asas hukum, yang mana asas hukum tersebut membentuk isi norma hukum. Nilai yang ada dan terumus menjadi suatu peraturan tidak sesuai dengan kondisi dan perkembangan masyarakat, maka timbullah pergeseran nilai yang berbeda dengan yang dahulu dengan diikuti pembaharuan dan/atau penyempurnaan norma kedepannya. Seperti halnya, anak luar kawin yang dahulu dibedakan haknya dengan anak sah walaupun sudah mendapatkan pengakuan dari ayahnya, kini tidak hanya dengan pengakuan saja anak luar kawin dapat diakui, namun juga dapat dibuktikan dengan perkembangan ilmu pengetahuan dan teknologi, yakni melalui tes DNA, serta haknya terhadap harta warisan dalam suatu pewarisan pun sama dengan anak sah, sehingga Pasal 863 KUHPerdata yang menyatakan anak luar kawin diakui yang mewaris bersama ahli waris golongan satu hanya berhak mendapatkan 1/3 bagian dari bagiannya jika ia adalah anak sah, kini bergeser menjadi anak luar kawin diakui 'dianggap sama' dengan anak sah dan memiliki hak yang sama terhadap bagiannya dalam suatu pewarisan.

Pergeseran nilai tersebut juga diikuti dengan berubahnya asas yang berupa prinsip-prinsip umum yang berlaku dalam masyarakat yang 
mendasari terbentuknya pembaharuan dalam suatu peraturan, dimana kedepannya akan ada Hukum Kewarisan Nasional yang akan berlaku bagi seluruh warga Indonesia sebagai hasil dari kodifikasi dan unifikasi hukum kewarisan yang pluralistis sebelumnya. Hukum kewarisan nasional ini masih berbentuk rancangan yang mana belum memiliki kekuatan hukum sebagai suatu aturan perundang-undangan yang digunakan sebagai acuan dalam bertindak dan membuat keputusan. Prof. Abdul Gani pun menyatakan bahwa rancangan perundang-undangan tidak dapat memaksa orang untuk menerapkannya, tetapi kalau hakim memandang bahwa rancangan itu dapat menjadi hukum, itu akan menjadi hukum, yang dimungkinkan adalah mengambil pendapat perancang rancangan undang-undang tersebut menjadi hukum. Dimana pendapat perancang undang-undang merupakan hasil penilaian si perancang terhadap sesuatu yang kemudian ia tuangkan dalam suatu rancangan perundang-undangan, yang kemudian dalam hal ini hakim menganut nilai yang sama terhadap suatu hal seperti si perancang tersebut. Rancangan perundang-undangan tidak dapat dijadikan dasar hukum dalam mengambilkan putusan, akan tetapi nilai dapat menjadi dasar dalam pembaharuan hukum. Selaras dengan teori Max Scheler yang mengelompokkan nilai menjadi:

1. Nilai kenikmatan (rasa enak, nikmat, senang) yang menyangkut kesenangan dan ketidak-senangan terdapat dalam objek yang dapat dilihat oleh indra mahluk hidup. Objek tersebut dapat dinilai menyenangkan atau tidak menyenangkan bergantung pada mahluk hidup yang memiliki indra tersebut, akan tetapi nilai objek itu sendiri akan tetap sama;

2. Nilai kehidupan (kesehatan, kesegaran, jasmaniah) yang menyangkut vitalitas;

3. Nilai kejiwaan (kebenaran, keindahan) yang menyakut nilai estetis, baik atau buruk, benar ataupun salah. 
4. Nilai kerohanian (kesucian) yang menyangkut objek-objek absolut, terdapat dalam bidang religius.

Max Scheler merumuskan bahwa nilai erat kaitannya dengan kegiatan menimbang, menghubungkan sesuatu dengan sesuatu yang lain, yang kemudian dilanjutkan dengan memberikan keputusan, sebagaimana putusan dalam studi kasus ini yang didasari oleh nilai yang berkembang dalam masyarakat, dimana kini masyarakat sudah tidak lagi membedakan anak luar kawin diakui dengan anak sah. Kaitannya dalam kasus ini, dimana ada perkara pewarisan antara para ahli waris dan pengadilan memutus dan menetapkan ahli waris beserta bagiannya masing-masing, hakim dalam hal ini menghubungkan norma (peraturan perundang-undangan) yang berlaku dengan nilai yang berlaku dalam masyarakat yang mana terdapat perbedaan antara norma yang berlaku dengan nilai yang berkembang dalam masyarakat kini, kemudian hakim menimbang dengan segala pertimbangannya, seperti pandangan akan adanya unifikasi hukum dalam Hukum Kewarisan Nasional, argumentum per analogiam yang menganalogikan anak luar kawin diakui dengan anak anak angkat, serta guna mencapai tujuan hukum yang utama, yakni keadilan. Berdasarkan hal tersebut, hakim memutuskan anak luar kawin diakui berhak atas bagian yang sama dengan anak sah dikarenakan anak luar kawin diakui 'dianggap sama' dengan anak sah.

\section{PENUTUP}

\section{A. Kesimpulan}

Anak luar kawin diakui diatur bagiannya dalam hal pewarisan bersama golongan satu oleh KUHPerdata yang menyatakan anak luar kawin diakui mewaris $1 / 3$ bagian, dari mereka yang sedianya harus mendapat, seandainya mereka adalah anak sah (Pasal 863 KUHPerdata). Terlihat dalam studi kasus ini bahwa adanya pergeseran nilai hak waris terhadap anak luar kawin diakui yang didukung dengan argumentum per analogiam yang menganalogikan 
analogi anak angkat dan anak luar kawin diakui dalam hal pewarisan, teori tujuan hukum yang lebih mengutamakan keadilan dengan memperhatikan prinsip kebebasan dan prinsip persamaan atas kesempatan yang sama selama memberikan manfaat dan tidak merugikan bagi orang lain, teori sistem hukum yang tidak hanya mengacu pada substansi hukum (peraturan perundang-undangan yang berlaku), tetapi juga melihat kultur atau budaya hukum, sehingga pergeseran nilai terjadi dalam hal hak waris terhadap anak luar kawin diakui di mana kini bagiannya 'dianggap sama' dengan anak sah.

\section{B. Saran}

1. Dalam hal terjadi pergeseran nilai hak waris, perlu memperhatikan kultur hukum yang lebih mengarah pada sikap masyarakat, kepercayaan masyarakat, nilai-nilai yang dianut masyarakat dan ide-ide atau pengharapan mereka yang menentukan bagaimana sistem hukum memperoleh tempat yang sesuai dan dapat diterima oleh warga masyarakat dalam kerangka budaya masyarakat.

2. Pergeseran nilai hak waris tersebut terhadap anak luar kawin diakui perlu lebih memperhatikan akibat kepada ahli waris golongan lainnya

\section{DAFTAR PUSTAKA}

\section{A. Buku}

Afandi, Ali. Hukum Waris, Hukum Keluarga, dan Hukum Pembuktian. Cetakan ke-4. Jakarta: PT Rineka Cipta, 2004.

Apeldoorn, L.J. van. Pengantar Ilmu Hukum, diterjemahkan oleh Oetarid Sadino. Jakarta: Pradnya Paramita, 1993.

Diantha, I Made Pasek. Metodologi Penelitian Hukum Normatif dalam Justifikasi Teori Hukum, Cetakan ke-1. Jakarta: Prenada Media Group, 2016.

Erwin, Muhamad. Filsafat Hukum: Refleksi Kritis terhadap Hukum dan Hukum Indonesia (dalam Dimensi Ide dan Aplikasi). Jakarta: PT Raja Grafindo Persada, 2011. 
Judiasih, Sonny Dewi. Harta Benda Perkawinan Kajian terhadap Kesetaraan Hak dan Kedudukan Suami dan Isteri atas Kepemilikan Harta dalam Perkawinan. Cetakan ke-1. Bandung: PT Refika Aditama, 2015.

Klaseen, J.G. dan J.E. Eggens. Hukum Waris Bagian 1, Saduran dari Huwelijks Goederen en Erfrecht, Literatur Wajib pada Jurusan Notariat Fakultas Hukum Universitas Indonesia. Jakarta:1979.

Marzuki, Peter Mahmud. Penelitian Hukum. Edisi Revisi. Jakarta: Kencana Prenada Media Group, 2009.

ND, Mukti Fajar dan Yulianto Achmad. Dualisme Penelitian Hukum Normatif dan Empiri. Yogyakarta: Pustaka Belajar, 2015.

Oemarsalim. Dasar-Dasar Hukum Waris di Indonesia. Cetakan ke-6. Jakarta: PT Rineka Cipta, 2006.

Subekti. Pokok-pokok Hukum Perdata. Cetakan ke-31. Jakarta: Intermasa, 2003.

Suriasumantri, Jujun S. Filsafat Ilmu. Cetakan ke-3. Jakarta: Pustaka Sinar Harapan, 1987.

\section{B. Peraturan Perundang-Undangan}

Indonesia. Kitab Undang-Undang Hukum Perdata. . Undang-Undang Nomor 1 Tahun 1974 tentang Perkawinan.

- Peraturan Pemerintah Republik Indonesia Nomor 9 Tahun 1975 tentang Pelaksanaan Undang-Undang Nomor 1 Tahun 1974 tentang Perkawinan.

\section{Putusan Pengadilan}

Indonesia. Putusan Pengadilan Negeri Jakarta Pusat Nomor 239/Pdt.G/2015/PN,JKT,PST.

\section{Wawancara}

Peneliti. Wawancara, dengan Eko Sugianto, S.H., M.H., selaku Hakim Ketua Majelis dalam Putusan Nomor 239/PDT.G/2015/PN.JKT.PST, (Jakarta, 30 April 2018).

. Wawancara, dengan Dr. Tjempaka, S.H., M.H., M.Kn., selaku Notaris dan Dosen di Fakultas Hukum Universitas Tarumanagara, (Jakarta, 25 April 2018).

. Wawancara, dengan Prof. Dr. Abdul Gani Abdullah, selaku Guru Besar dan Mantan Hakim Agung bagian Perdata, (Jakarta, 22 Mei 2018). 